Rev. Mus. Argentino Cienc. Nat., n.s.

7(1): 37-41, 2005

Buenos Aires, ISSN 1514-5158

\title{
Giant titanosaur (Dinosauria, Sauropoda) from the Late Cretaceous of Patagonia
}

\author{
Fernando E. NOVAS ${ }^{1,2}$, Leonardo SALGADO ${ }^{3}$, Jorge CALVO ${ }^{4}$ \& Federico AGNOLIN ${ }^{2}$ \\ ${ }^{1}$ CONICET- ${ }^{2}$ Laboratorio de Anatomía Comparada, Museo Argentino de Ciencias Naturales «Bernardino \\ Rivadavia», Av. Angel Gallardo 470, Buenos Aires (1405), Argentina- ${ }^{3}$ Museo de Geología y Paleontología, \\ Universidad Nacional del Comahue, Buenos Aires 1400, (8300) Neuquén, Argentina- ${ }^{4}$ Centro Paleontológico \\ Lago Barreales, Universidad Nacional del Comahue, Ruta Prov. 51, km 65. Neuquén.
}

\begin{abstract}
We report the discovery of a new titanosaurian taxon, Puertasaurus reuili gen. et sp. nov., from Maastrichtian beds of SW Patagonia. Four vertebrae were recovered (i.e., cervical 9, dorsal 2, and two midcaudals). The new form is diagnosed on the basis of an inflated neural spine on cervical vertebra, and extremely short second dorsal vertebra, among other features. Puertasaurus is one of the largest known sauropod dino-saurs, with dorsal vertebra 2 measuring $168 \mathrm{~cm}$ in transverse width. This is the first time that a cervical verte-bra is reported for a giant titanosaur, giving a new insight on neck anatomy of neosauropod dinosaurs.
\end{abstract}

Key words: Sauropoda, Titanosauria, Cretaceous, Patagonia.

The Titanosauria is a diverse and geographically widespread clade of Cretaceous neosauropods, abundant in Upper Cretaceous rocks of South America (Salgado et al., 1997; Powell, 2003; Wilson \& Upchurch, 2003). Many titano-saurs were large, but just a few (e.g., the Ceno-manian Argentinosaurus huinculensis and the Turonian «Antarctosaurus» giganteus; Huene, 1929; Bonaparte \& Coria, 1993) are known to have attained truly gigantic sizes (up to 35 meters long and around 80 tons). Because known specimens of these giant sauropods are incomplete, many aspects of their anatomy and systematics remain obscure. Here we report the discovery of a new Patagonian sauropod, Puertasaurus reuilli gen et sp. nov., one of the largest of these giant tetrapods. This is the first time in which a cervical vertebra is reported for a giant titanosaur, making it possible to compare it with smaller members of the clade.

We follow the taxonomy proposed by Salgado (2003).

\section{SYSTEMATIC PALEONTOLOGY}

Sauropoda Huene, 1932

Titanosauriformes Salgado, Coria \& Calvo, 1997

Titanosauria Bonaparte \& Coria, 1993

Titanosauridae Lydekker, 1893

\section{Puertasaurus reuili gen et sp. nov.}

Etymology. In honor to Pablo Puerta and Santiago Reuil, remarkable fossil-hunters who discovered and prepared the specimen.
Holotype. MPM (Museo Padre Molina, Río Gallegos, Santa Cruz) collection number 10002, consisting of four disarticulated vertebrae, including most of a cervical vertebra, a complete dorsal 2, and the centra of two caudal vertebrae.

Locality and Horizon. Cerro Los Hornos, La Leona, Santa Cruz Province, Argentina. Pari Aike Formation, early Maastrichtian (Kraemer \& Riccardi, 1997; Novas et al., 2004a). Vertebrae were found in situ in a fine, gray sandstone lens, containing highly carbonized plant remains classified as cycads and conifers on the basis of cuticular morphology (L. Villar de Seoane, pers comm.). Dinosaurs recorded in the Pari Aike Formation are the basal iguanodontian

Talenkauen santacrucensis (Novas et al., 2004a) and a large, yet undescribed, derived tetanuran theropod (Novas et al., 2004b).

Diagnosis. Puertasaurus reuili is diagnosed on the basis of the following combination of characters: gigantic size; cervical neural spine considerably inflated, being transversally wider than the vertebral centrum and bearing strong dorsolateral ridges; caudal cervicals with spinoprezygapophyseal laminae transversely thick and dorsoventrally deep; cranial dorsal vertebrae extremely short, more so than in other sauropods (e.g., centrum width/centrum length:1; in all other titanosauriforms, this ratio is less than 1).

Description. For the first time a cervical vertebra of a giant titanosaur is documented (Fig. 1). The neck vertebra (presumably cervical 9 ) is 118 $\mathrm{cm}$ long (between pre- and postzygapophyses) and although mid-cervicals of the Early Creta- 

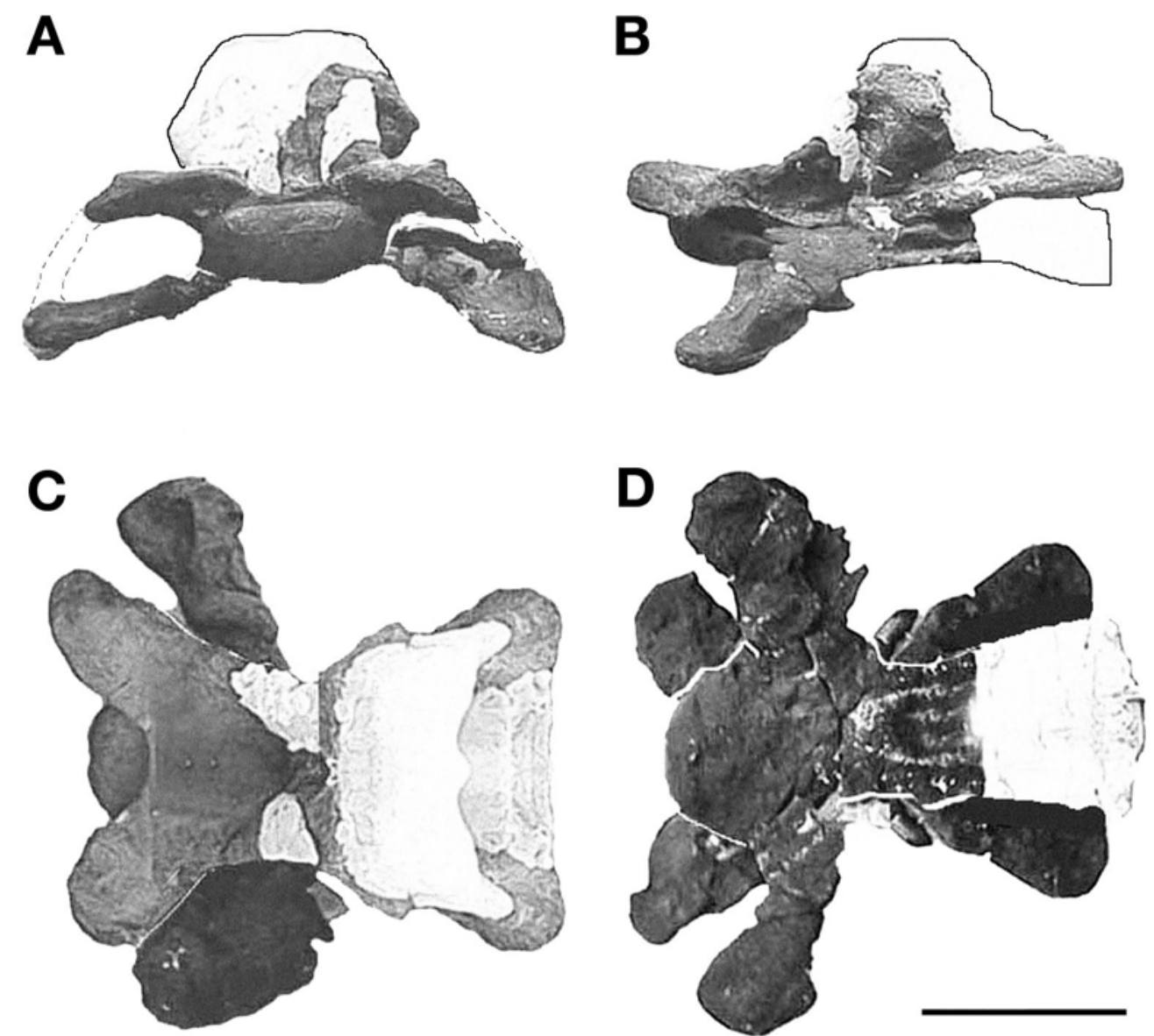

Fig. 1. A-D, Puertasaurus reuili gen. et sp. nov. (MPM-10002, Río Gallegos), cervical 9 in cranial (A), lateral (B), dorsal (C), and ventral (D) views. Scale bar $50 \mathrm{~cm}$.

ceous brachiosaurid Sauroposeidon (Wedel et al., 2000) are longer than the cervical of the new titanosaur, the latter one is exceptionally wide with a transverse width of $140 \mathrm{~cm}$ (including fused ribs). The neural spine bears deep and wide pre- and postspinal fossae for cradling well-de-veloped interspinous ligaments, as well as a con-siderably inflated distal end, suggesting a pow-erful neck ligament and cervical muscles. Such characters are insinuated in smaller titanosaurs, but they reach an extreme development in the new form. The dorsal enlargement of the neural spine is derived with respect to the transversely narrower neural spine of all other titanosau-riforms (e.g., Brachiosaurus, Euhelopus, Neu-quensaurus ; Fig. 3), and sharply differs from the bifid spines of diplodocoids. This peculiar neural spine is associated with a set of titanosaurian features (e.g., Upchurch, 1999), such as laterally projecting diapophyses and parapophyses, and a low neural arch with a high neural spine. In the new specimen, the zygapophyseal articulations are positioned low on the neural arch, and the centrum is even more depressed than in other titanosaurids (e.g., Saltasaurus). Consequently, the system of bony struts on the sides of the vertebra (and the pneumatic fossae they define) are dorsoventrally flattened. The cervical vertebra is poorly pneumatized and lacks pleurocoels.

The available dorsal (dorsal 2) vertebra is craniocaudally short, in sharp contrast with the cervical described above (Fig. 2). The centrum is strongly opisthocoelous and proportionally shorter than in other Titanosauridae. Hypos-phenehypantrum articulations are absent. Al-though the lack of these structures is diagnostic of Titanosauridae (Salgado et al., 1997; Bonaparte, 1999), their absence in Puertasaurus may be due to the cranial position of this vertebra.

Dorsal 2 of Puertasaurus is $106 \mathrm{~cm}$ in height but $168 \mathrm{~cm}$ from the ends of the wing-like transverse processes, thus exceeding by nearly $45 \mathrm{~cm}$ 

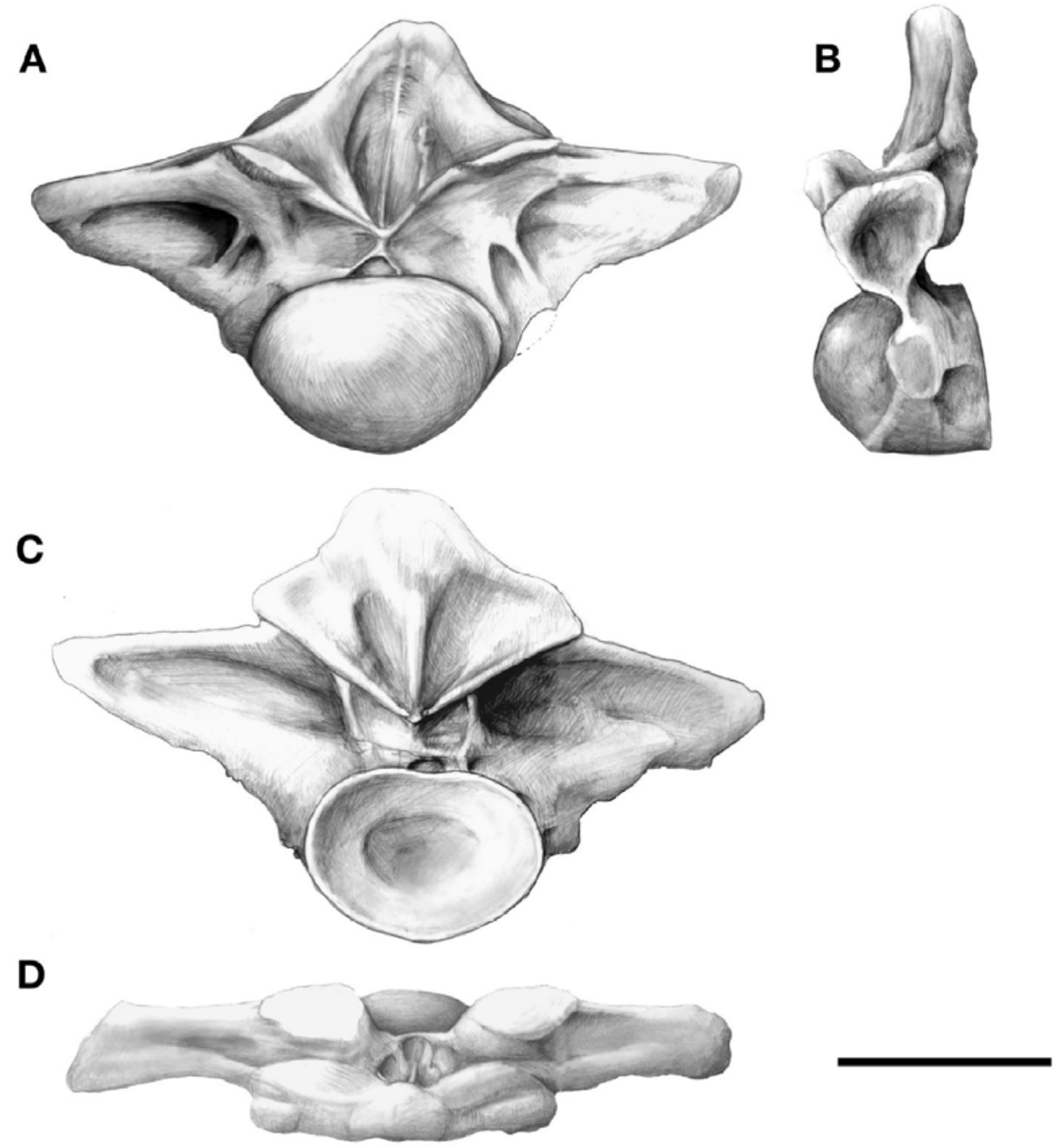

Fig. 2. A-D, Puertasaurus reuili gen. et sp. nov. (MPM-10002, Río Gallegos), dorsal 2 in cranial (A), left lateral (B), caudal (C), and dorsal (D) views. Scale bar $50 \mathrm{~cm}$.

dorsal 4? of Argentinosaurus huinculensis, considered to be one of the biggest dinosaurs (Bonaparte \& Coria, 1993; Paul, 1994). This dorsal is considerably wider (in absolute terms) than in other known sauropod. Transverse processes are dorsoventrally deep at their bases, resulting in a wing-like appearance in cranial view (Fig. 2), as in the basal titanosauriform Euhelopus (Wiman, 1929). In Puertasaurus the transverse processes of dorsal 2 are perpendicular to the axial plane (Fig. 2D), as is the case in Argentinosaurus and Euhelopus, instead of being laterocranially oriented as in more derived titanosaurids (e.g., Saltasaurus, Titanosauridae indet. «Series B»; Powell, 2003). The neural spine is dorsoventrally low but transversely expanded, as usually found among Titanosauridae (Powell, 2003) . The neural spine is vertically oriented, being perpendicular in respect to the craniocaudal axis of centrum, thus resembling Argenti-nosaurus, for example. The system of laminae in the neural arch is reduced but robust, and it shows pre- and postspinal laminae diagnostic of titanosaurs (Upchurch, 1999). The pre- and postspinal fossae of Puertasaurus are wider and deeper than in more derived titanosaurids (e.g.,

Saltasaurus, Opisthocoelicaudia; Powell, 2003; Borsuk-Bialynicka, 1977), resembling in this fea- 
A
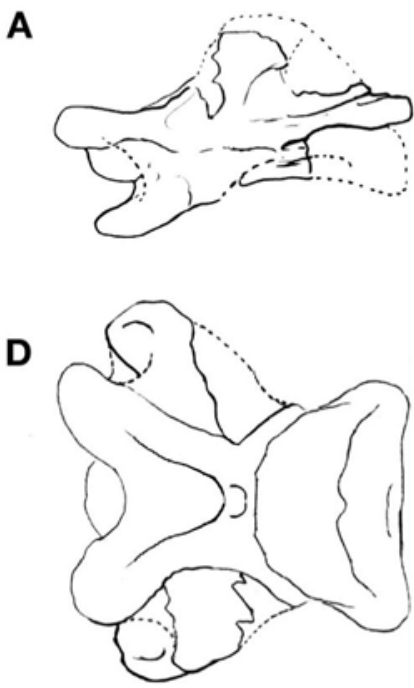

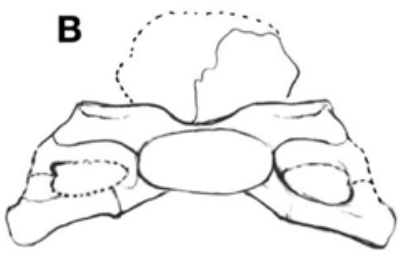

$\mathbf{E}$

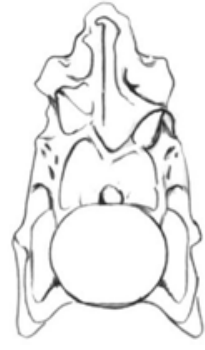

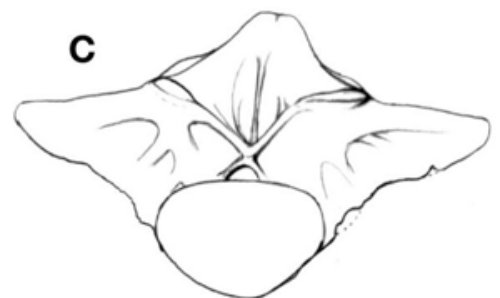

$\mathbf{F}$

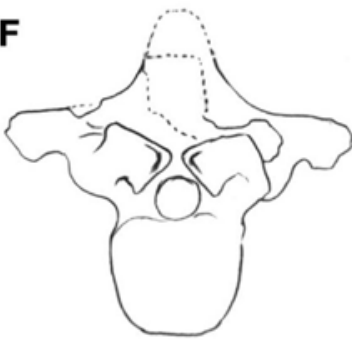

Fig. 3. Comparison among cervical and dorsal vertebrae of some selected sauropods. A, B, D, Puertasaurus reuili gen. et sp. nov., cervical 9 in lateral (A), cranial (B), and dorsal (D) views. C, Puertasaurus reuili gen. et sp. nov., dorsal 2 in cranial view; E, Brachiosaurus brancai, cervical vertebra in cranial view (Janensch, 1950); F, Argentinosaurus huinculensis, dorsal 4? in cranial view (modified from Bonaparte \& Coria, 1993). Scale $50 \mathrm{~cm}$.

ture basal titanosauriforms such as Euhelopus and Brachiosaurus (Bonaparte, 1999).

Two mid-caudal centra are preserved. They are procoelous, a common feature among Titanosauridae (Salgado et al., 1997).

Discussion. Puertasaurus reuili exhibits the following synapomorphic features of Titanosauriforms: 1) deep and wide pre- and postspinal fossae in cervical and dorsal vertebrae; 2 ) very elongated cervical centra (Wilson, 2002); 3) reduced cervical neural arch lamination; and 4) presence of prespinal laminae in dorsal vertebrae (Salgado et al., 1997). Puertasaurus is referred to Titanosauria because it shows the following derived features: 1) cervicals with laterally projecting diapophyses and parapophyses (Upchurch, 1999); 2) low neural arch with a relatively high neural spine (Salgado et al. 1997; Bonaparte, 1999); and 3) dorsal vertebrae with robust preand postspinal laminae (Upchurch, 1999). Puertasaurus exhibits two titanosaurid features: 1) neural spines of dorsal vertebrae dorsoventrally low and transversally expanded (Salgado et al. 1997; Bonaparte, 1999); and 2) procoelous mid-caudal vertebrae. Moreover, the new taxon bears a well developed prespinal lamina in dorsal 2, a feature interpreted as diagnostic of Eutitanosauria (Salgado, 2003). Nevertheless, Puertasaurus lacks some of the synapomorphies of Titanosauridae: for example, cranial dorsals of the new taxon retained vertical neural spines and transverse processes that are perpendicularly oriented, and neural arches that lack the complex system of laminae and pneumatic depressions characteristic of derived titanosaurids. In conclusion, Puertasaurus is interpreted as a possible basal titanosaurid.

Puertasaurus and Argentinosaurus are the largest known sauropods. However, Puertasaurus differs from the latter one in having dorsal ver-tebrae with large, wing-like transverse processes, lower neural spine, thick postspinal laminae, and cranial dorsals craniocaudally shorter. We con-sider such distinctions enough to distinguish both taxa, a conclusion that is in agreement with the stratigraphical provenance of these dinosaurs: Puertasaurus comes from Maastrichtian beds, while Argentinosaurus is Cenomanian in age.

The evidence at hand suggests that basal titanosaurian clades were prone to attain big sizes. In contrast, more derived Titanosauridae include not only medium sized members, but also the smallest adult known sauropods (e.g.,

Neuquensaurus, Saltasaurus , Magyarosaurus; Jianu \& Weishampel, 1999). It was suggested (Bonaparte \& Coria, 1993) that in South America sauropods attained their maximum sizes between Aptian and Coniacian times. The discovery of Puertasaurus in Maastrichtian beds demonstrates that gigantic sizes of South American sauropods endured up to the end of the Mesozoic Era, an interpretation that is in agreement with other findings of big sauropod bones in the Pari Aike Formation (Lacovara et al., 2004). Exepting 
southernmost Patagonia, the remaining Maastrichtian fossil sites with sauropods in South America (Powell, 2003), Madagascar (CurryRogers \& Forster, 2001), and Europe (Jianu \& Weishampel, 1999), the documented titanosaurs are consider-ably smaller than Puertasaurus.

Up to now, the biggest Cretaceous dinosaurs (e.g., Argentinosaurus huinculensis, "Antarctosaurus» giganteus, and Puertasaurus reuili) were documented in South America. Why such gigantic vertebrates evolved in this continent is puzzling. We suggest that this may reflect the evolution in progressive isolation of sauropods on this continent during the Cretaceous.

The discovery of Puertasaurus demonstrates that disparity in neck anatomy among sauropod dinosaurs is greater than suspected (Fig. 3). The low and wide titanosaurian cervicals differ from the deep cervicals of the remaining neosauropods (e.g., diplodocids, Brachiosaurus, and Euhelopus) in that the latter exhibit rounded articular surfaces of the centra, ribs mostly ventrally oriented, and zygapophyses occupying an elevated position with respect to the centrum (Fig. 3E). Such anatomical distinctions, not recognized before, remain unexplored from mechanical, postural and movemental points of view, and may have important consequences for functional studies of sauropod necks (Wedel et al., 2000; Stevens \& Parrish, 1999).

\section{ACKNOWLEDGEMENTS}

Thanks to Eduardo Vidal and his family for the logistic support received during field exploration. Pablo Puerta, Santiago Reuil, Juan Canale, Alejandro Haluza, Gastón Lo Coco, Juan Goroso, and Daniel Hauk for their work in the field. Greg Paul, Mike Parrish, Olivier Rauhut, and Rodolfo Coria for their valuable comments on our manuscript. Drawings were executed by Gabriel Lío, and photographs by Hernán Canutti. Field work and study was supported by the National Geographic Society, Conicet, Agencia Nacional de Promoción Científica y Tecnológica, Vialidad Nacional, Akapol $\mathrm{SA}$, and Renault Argentina (Buenos Aires).

\section{BIBLIOGRAPHY}

Bonaparte, J.F. 1999. Evolución de las vértebras presacras en Sauropodomorpha. Ameghiniana 36: 115-187.

Bonaparte, J.F. \& R.A. Coria. 1993. Un nuevo y gigantesco saurópodo titanosaurio de la Formación Río (Albiano-Cenomaniano) de la provincia de Neuquén, Argentina. Ameghiniana 30: 271-282.

Borsuk-Bialynicka, M. 1977. A new camarasaurid sau- ropod Opistocoelicaudia skarzynskii gen. n., sp. n., from the Upper Cretaceous of Mongolia. Re-sults of the Polish-Mongolian Palaeontological Expeditions - Part VII. Palaeont. Pol., 37: 5-64.

Curry-Rogers, K. \& C. Forster. 2001. The last of the dinosaur titans: a new sauropod from Madagascar. Nature 412: 530-534.

Huene, F. von. 1929. Los saurisquios y ornitisquios del Cretáceo argentino. An. Mus. La Plata 3: 1-194.

Janensch, W. 1950. Die Wirbelsäule von Brachiosaurus brancai. Palaeontographica 7: 27-93.

Jianu, C.M. \& D.B. Weishampel. 1999. The smallest of the largest: a new look at possible dwarfing in sauropod dinosaurs. Geologie et Minjbow 78: 335-343.

Kraemer, P. \& A. Riccardi. 1997. Estratigrafía de la región comprendida entre los lagos Argentino y Viedma (49ú 40' - 50ú 10' la S), provincia de Santa Cruz. Rev. Asoc. Geol. Argentina 52: 333-360.

Lacovara, K., J. Harris, M. Lammana, F. Novas, R. Martínez \& A. Ambrosio. 2004. An enormous sauropod from the Maastrichtian Pari Aike Formation of southernmost Patagonia. Journ. Vert. Paleo., 24(3): 81A (Suppl).

Novas, F.E., A.V. Cambiaso \& A. Ambrosio. 2004a. A new basal iguanodontian (Dinosauria, Ornithischia) from the Upper Cretaceous of Patagonia.

Ameghiniana 41: 75-82.

Novas, F.E., A. Lecuona, J.O. Calvo \& J.D.Porfiri. 2004b. Un terópodo del Cretácico Superior de la Provincia de Santa Cruz. Ameghiniana 41(4): 59R.

Paul, G.S. 1994. Big sauropods-Really, really big sauropods. The Dinosaur Report: 12-13.

Powell, J.E. 2003. Revision of South American titanosaurid dinosaurs: palaeobiological, palaeobiogeographical and phylogenetic aspects. Records Queen. Vict. Mus. 111: 1-173.

Salgado, L. 2003. Should we abandon the name Titanosauridae? Some comments on the taxonomy of titanosaurian sauropods (Dinosauria). Rev. Española Paleont. 18: 15-21.

Salgado, L., R.A. Coria \& J. Calvo. 1997. Evolution of titanosaurid sauropods I: Phylogenetic analysis based on the postcranial evidence. Ameghiniana 34: 3-32.

Stevens, K. \& J.M. Parrish. 1999. Neck posture and feeding habits of two Jurassic sauropod dinosaurs. Science 284: 798-800.

Upchurch, P. 1999. The phylogenetic relationships of the Nemegtosauridae (Saurischia: Sauropoda). J. Vert. Paleont. 19: 106-125.

Wedel, M.J., R.L. Cifelli \& K. Sander. 2000. Osteology, paleobiology, and relationships of the sauropod dinosaur Sauroposeidon. Acta Paleont. Pol. 45: 343-388.

Wilson, J. 2002. Sauropod dinosaur phylogeny: critique and cladistic analysis. Zool. Jour. Linn. Soc. 136: 217-276.

Wilson, J., \& P. Upchurch. 2003. A revision of Titanosaurus Lydekker (Dinosauria-Sauropoda), the first dinosaur genus with a 'Gondwanan' distribution. J. Syst. Palaeont. 1: 125-160.

Wiman, C. 1929. Die Kreide-Dinosaurier aus Shantung. Palaeont. Sin. 6: 1-67. 